\title{
A Hirnantian deep-water refuge for warm-water ostracods in Baltoscandia
}

\author{
Karin TRUUVER ${ }^{1, *}$ and Tõnu MEIDLA ${ }^{1}$ \\ 1 University of Tartu, Institute of Ecology and Earth Sciences, Department of Geology, Ravila 14A, Tartu, Estonia
}

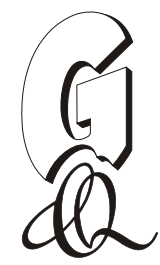

Truuver, K., Meidla, T., 2015. A Hirnantian deep-water refuge for warm-water ostracods in Baltoscandia. Geological Quarterly, 59 (4): 738-749, doi: 10.7306/gq.1258

\begin{abstract}
The latest Ordovician is marked by a severe climate change, the Hirnantian glaciation. This climatic event affected many marine taxa including ostracods. Rich and abundant ostracod assemblages of the Baltic Palaeobasin were severely impoverished. Many of the typical pre-Hirnatian warm-water ostracod species died out, but also some distinct, cold-water species appeared. Two very different but likely coeval latest Ordovician ostracod assemblages are recorded in the Baltic countries and northeastern Poland. The latest Ordovician Estonian Shelf (inner ramp) is characterized by the Medianella aequa association whilst sections in the Livonian Basin (middle to outer ramp) reveal the Harpabollia harparum association that is thought to represent a cold-water assemblage belonging to the Dalmanitina-Hirnantia Fauna sensu lato. A transitional assemblage composed of a "species mixture" of typical Hirnantian cold-water and some pre-Hirnantian warm-water ostracod species is described for the first time from the Kętrzyn IG 1 borehole, northeastern Poland. The assemblage is dominated by Cryptophyllus pius sp. $\mathrm{n}$. The genus Cryptophyllus is rare in the two other well-known assemblages. The discovery suggests that marginal parts of the Baltic Palaeobasin could serve as a kind of refuge for the last representatives of the ostracod faunas of the inner shelf of Baltic Palaeobasin. The Hirnantian assemblage is replaced by the low-diversity recovery assemblage that is dated as late Hirnantian-Silurian in Estonia and other areas. This suggests that the position of the systemic boundary in the Kętrzyn borehole and elsewhere in northeastern Poland should be re-evaluated.
\end{abstract}

Key words: Upper Ordovician, Baltic Palaeobasin, ostracods, northeastern Poland, Kętrzyn IG 1 borehole.

\section{INTRODUCTION}

The latest Early to Late Ordovician ostracod fauna is one of the best studied Ordovician ostracod faunas in the world. A major change in the faunal composition has been documented at the lower boundary of the Oandu Stage, Lower Katian (see Meidla, 1996b), equivalent to the Dicranograptus clingani graptolite Zone; Meidla et al., 2014), slightly above the Guttenberg Isotope Carbon Excursion (GICE) event (Hints et al., 1989; Bergström et al., 2010; Ainsaar et al., 2010). Another turnover in the taxonomic composition of ostracods occurs at the Ordovician-Silurian boundary, coinciding with the major sea level fall and major extinction that is ascribed to the Hirnantian glaciation event at the very end of the Ordovician. The Baltoscandian ostracod record between these events is well known and the fauna as a whole is taxonomically uniform (Hints et al., 1989; Meidla, 1996b). The aim of this study is to compare faunal composition of ostracod assemblages and changes within them in different parts of the Baltic Palaeobasin during the Upper Ordovician (Fig. 1). The main focus is placed on the changes in the ostracod assemblage collected from the

\section{* Corresponding author, e-mail: karin.truuver@ut.ee}

Received: May 5, 2015; accepted: October 27, 2015; first published online: November 12, 2015
Kętrzyn IG 1 borehole (NE Poland) due to the end-Ordovician glaciation. We also compare the changes in this assemblage to changes in the coeval assemblages described in other parts of the Baltic Palaeobasin.

\section{PREVIOUS STUDIES}

A very specific ostracod assemblage was recovered by Gailite (1970) from the core sections of West Latvia. This fauna was first recovered from the Kuldiga Member, a thin subsurface unit that was first attributed to the topmost Ordovician or basal Silurian by Ulst and Gailite (1970). This assemblage was described as consisting mostly of new species (see Ulst and Gailīte, 1970: table 1) and only few rare taxa were more widely known. These weak faunal links with other areas were interpreted as suggesting a possible Ordovician level affinity (Ulst and Gailite, 1970).

Already in the first half of the 19th century a fossil assemblage of largely similar composition was collected from coeval strata at the construction site of the Göta Canal in Borenshult, SE Sweden (Meidla, 2007). The fauna remained undescribed for a long time. Isolated elements of the same assemblage were found also in other locations in Scandinavia (e.g., Troedsson, 1918; Henningsmoen, 1954) but scarce isolated specimens did not deserve sufficient attention. Meidla (2007) published a detailed description of the specific ostracod collection gathered from Borenshult material and named it the Harpabollia harparum association, after the name of the most characteristic 
ostracod species. This diverse ostracod association is composed mostly of binodicopes. Four species, Harpabollia harparum (Troedsson), Circulinella gailitae Meidla, Rectella sturiensis (Gailite) and Aechmina groenwalli (Troedsson) constitute about $3 / 4$ of the total number of species. As a summary, the Harpabollia association is known today from the upper part of the Kuldiga Formation and from the Saldus Formation (regional formations in the Hirnantian Stage; corresponding to the extraordinarius and persculptus biozones, respectively) within the Livonian Basin (Gailīte, 1970; Ulst et al., 1982; Meidla, 1996b, 2007; Meidla et al., 2011), but also in Scania and Östergötland, Sweden (Troedsson, 1918; Meidla, 2007). This fauna is considered to belong to the Dalmanitina-Hirnantia Fauna sensu lato in the East Baltic region (Meidla, 2007).

In North Estonia the latest Ordovician is represented by the Ärina Formation corresponding to the lower part of the Porkuni Stage (North Estonian equivalent to the Hirnantian Stage; Kaljo et al., 2001) and representing the inner ramp reef facies. The ostracod association in these strata is dominated by metacopes, Steusloffina cuneata, Microcheilinella lubrica, Medianella aequa, $M$. intecta and $M$. longa, which are the most abundant species of the endemic North Estonian Medianella aequa ostracod association (distinguished by Meidla, 1996b). This assemblage contains very few elements in common with the Harpabollia harparum association in the southwestern part of Baltoscandia. The typical ostracod species that make their first appearance in the lowermost Hirnantian of that area, e.g. Harpabollia harparum, Aechmina groenwalli, Pseudoancora confragosa, Pseudulrichia disputabile, are all absent in the Ärina Formation (Meidla, 1996b, 2007).

A transitional assemblage between the inner ramp and outer ramp assemblages has not yet been described in Baltoscandia. The similar age of these two very distinct ostracod assemblages in Estonia suggests that a transitional fauna could possibly be present in Central Estonian strata, but due to dolomitization in the transition interval (Oraspõld, 1975) and erosion of the pre-Hirnantian-Hirnantian strata in the area (Hints and Männik, 2014), it has not been discovered.

\section{GEOLOGICAL BACKGROUND}

The Kętrzyn IG 1 borehole is situated in the northwestern part of the East European Craton (Modliński and Podhalańska, 2010), in the southern extension of the Scandinavian Basin (Central Baltoscandian Confacies belt area by Jaanusson, 1976; Fig. 1), south of the embayment known as the Livonian Basin (or Livonian Tongue). The area is mostly characterized by limestones deposited in a distal ramp setting (Ainsaar et al., 2004, 2010, 2015; Fig. 1).

Jaworowski $(1999,2002)$ has divided the lower Paleozoic strata of the East European Craton into four depositional sequences. The two lower depositional sequences comprise the Ediacaran to Lower Tremadoc. Depositional sequence III reaches from mid-Floian up to the lower boundary of the Silurian System and depositional sequence IV includes the strata from Llandovery to Přidoli (Modliński and Podhalańska, 2010). The Ordovician carbonate sequence in the Kętrzyn IG 1 borehole comprises mostly depositional sequence III with a thickness of $68.2 \mathrm{~m}$ (depth 1544.5-1612.7 m; Modliński et al., 2002). The upper part of the Ordovician succession in the Polish part of the eastern Baltic near-coastal areas comprises mostly marls and shaly marls, grey to dark grey mudstones and calcareous shales deposited in a distal ramp environment. The uppermost Ordovician Prabuty Formation corresponds to the Pirgu and Porkuni stages (Modliński and Podhalańska, 2010; Fig. 2). A regressive

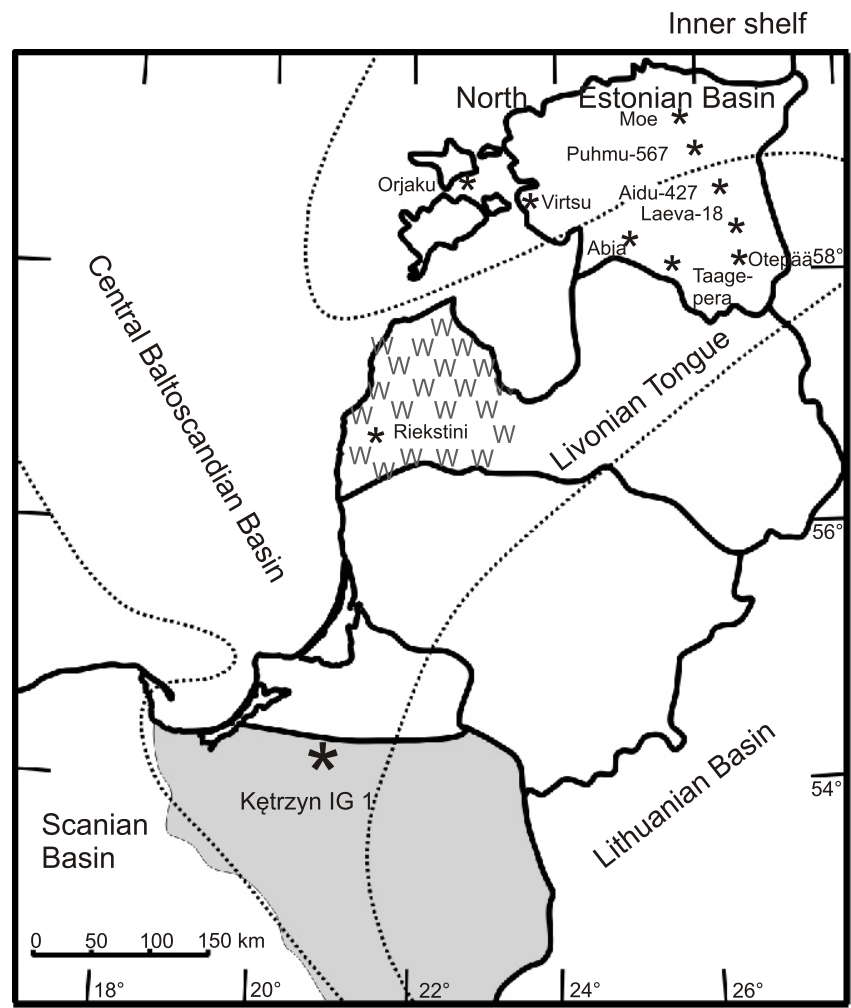

Outer shelf after Sztejn, W W Latvia (1985: fig. 1) W (western region)

Fig. 1. The depth zonation in the Baltoscandian Palaeobasin during the Late Ordovician (modified after Modliński et al., 2002: fig. 1)

Position of the palaeontologically studied boreholes in Estonia (Orjaku, Virtsu, Moe, Abja, Otepää, Taagepera, Puhmu-567, Aidu-427 and Laeva-18 drillcores - all according to Meidla, 1996b), Lithuania (Riekstini; Meidla in Brenchley et al., 2003) and in Poland (Kętrzyn IG 1 borehole; this paper); the dashed line outlines the "Confacies Belts" (after Jaanusson, 1976, 1995 in Modliński et al., 2007) largely reflecting the depth zonation in the palaeobasin

trend can be recognized in the Prabuty Fm., the marls and shales of the main part of this formation grade into sandstones (about $0.8 \mathrm{~m}$ thick) in its upper part. These sandstones correspond to the peak regression in the late Early Hirnantian, apparently marking the maximum glaciation and the respective glacioeustatic sea level fall related to climatic cooling (Brenchley et al., 2003; Modliński and Podhalańska, 2010).

The Kętrzyn area in northeastern Poland is quite well-studied. Studies have been conducted on lithology of the Upper Ordovician, Llandovery and Wenlock of northeastern Poland (e.g., Bednarczyk, 1968; Bednarczyk et al., 1996; Teller, 1997; Podhalańska, 1999; Modliński et al., 2002; Modliński and Podhalańska, 2010) and also on the fossils of the area. Górka (1969) studied acritarchs and phosphatic problematica (genera Labyrinthotuba, Phosphotesta and Oxytuba) in the Ordovician of Poland (using also data from the Kętrzyn IG 1 borehole), Biernat (1973) described Ordovician inarticulate brachiopods, Modliński et al. (2002) established the chitinozoan biozonation of the Ordovician in the Kętrzyn IG 1 borehole, and Stempień-Sałek (2011) described the Upper Ordovician palynomorph assemblages. 


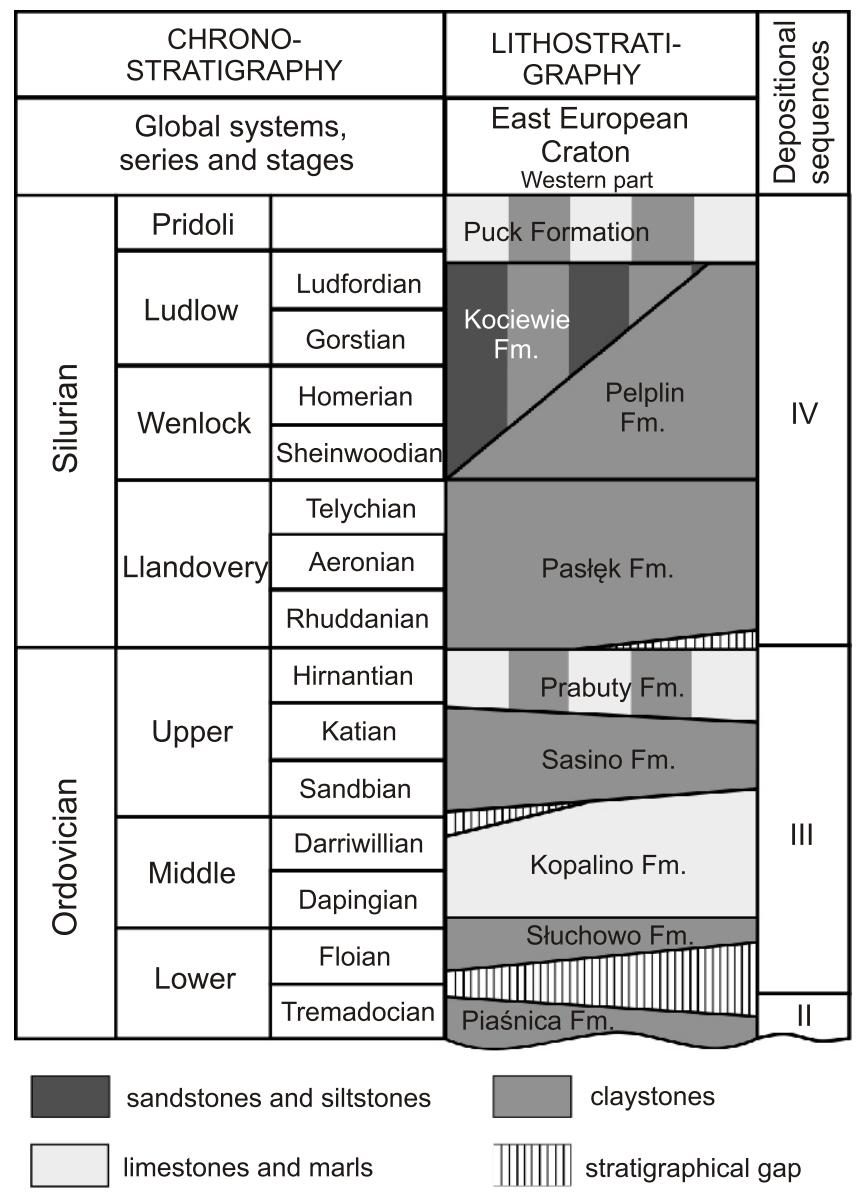

Fig. 2. Stratigraphic chart of the Polish part of the Ordovician and Silurian stratigraphy in the Baltic region (modified after Modliński and Podhalańska, 2010: fig. 2)

\section{MATERIAL AND METHODS}

The present paper is based on material collected from the Kętrzyn IG 1 drillcore by J. Nõlvak in 1987. The ostracods were picked from the fossiliferous marl before dissolving the rock samples for extraction of chitinozoans. Samples collected from the uppermost Ordovician-Silurian transition interval of the borehole comprise mostly marls (calcareous mudstones). The topmost part of the Prabuty Formation, a thin (about $0.8 \mathrm{~m}$ thick) unit of sandy limestones has not been sampled. Ostracods were examined under the optical microscope; SEM microphotographs were taken with a Zeiss EVO MA15 SEM scanning electron microscope in the Department of Geology, University of Tartu. The collection number is GIT-698 and it is currently deposited in the Department of Geology of Tallinn University of Technology, Estonia.

\section{SYSTEMATIC PALAEONTOLOGY}

Class Ostracoda Latreille, 1802 Order Beyrichiocopida Pokorny, 1954 Suborder Eridostraca Adamczak, 1961 Family Cryptophyllidae Adamczak, 1961
Genus Cryptophyllus Levinson, 1951

Species Cryptophyllus pius sp. n.

H o l o t y p e. - right valve GIT 698-32 (Fig. 3D). Poland, Kętrzyn IG 1 borehole, depth 1551.2 m, Hirnantian Stage, Upper Ordovician.

Diagnosis. - Carapace amplete, medium- to large-sized, reaching considerably over $1 \mathrm{~mm}$ in length in some cases. Valves are lamellar and pitted, with vague median sulcus. Adductor muscle scar is star-shaped in some specimens. The average maximum number of layers is 3 . Dorsal line is long and straight.

Dimensions of the holotype (GIT 698-32): length $-0.89 \mathrm{~mm}$, height $-0.67 \mathrm{~mm}$.

Description. - Carapace is amplete, medium- to large-sized, with average length ranging from 1.22 to $1.35 \mathrm{~mm}$, and average height from 0.86 to $0.95 \mathrm{~mm}$. The carapace is thickest just under the muscle scar, in measured specimen GIT 698-35 (Fig. 3G) the maximum carapace thickness is $0.57 \mathrm{~mm}$. Valves are multilamellar with probably mostly up to 3 layers. Valve surface is pitted with large pits (ca. 22-23 $\mu \mathrm{m}$ ). Median sulcus is vague but visible and longer than that of Cryptophyllus gutta. Adductor muscle scar (pit S2) is sometimes star-shaped, and emerges better and clearer on specimens that are lacking upper layers. On carapaces that are better preserved and possess upper layers the muscle scar is vague. Dorsal line is long and straight, cardinal corners are quite round and at times difficult to determine.

Comparison. - The number of species of Cryptophyllus is close to 40 (Mees et al., 2015) but this includes also records from the Silurian and Devonian. This material is in need of a revision, as different authors have used different and partly arbitrary criteria (for example, number of preserved juvenile valves; e.g., Schallreuter, 1968, 2010) for distinguishing individual species. As a revision of the genus is not possible in this paper, we will limit the discussion to the type species and to the Baltoscandian material.

The only species that is widely common in the Late Ordovician of Baltoscandia is $C$. gutta. The validity of another species (Pygoconcha baltica Schallreuter, 1987) is questioned by Sidaravičiene (1992: 186) who suggested this to be another synonym of $C$. gutta. Trilamellar specimens of $C$. gutta were described as Pygoconcha trilamellae by Schallreuter (1968) and later (Abushik and Sarv, 1983; Meidla, 1996b) assigned to C. gutta. Compared to C. gutta and to the type species of the genus Eridoconcha oboloides Ulrich et Bassler 1923, the carapace of $C$. pius sp. n. is much larger, and carapace length of some adult specimens remarkably exceeds $1 \mathrm{~mm}$. Valve retention characteristic of Eridoconchidae (Kay, 1940) is present also in $C$. pius but the number of valves does not exceed three in our collection. The highest number of valve layers recorded in Cryptophyllus is 15 (Cryptophyllus sp.; Becker and Bless, 1974 in Olempska, 2012). The dorsal hinge line that is short in C. gutta, is long and straight in C. pius sp. n. Both C. gutta and C. pius sp. n. possess a vague median sulcus, but in $C$. gutta it is short and situated on an emerging umbone. In $C$. pius the sulcus is long and ends with a deeper depression marking the position of the adductor muscle attachment. The scar, that is sometimes star-shaped, is situated between two low umbos/lobes. Valve surface of $C$. pius is pitted with relatively large (ca. 22-23 $\mu \mathrm{m}$ ) pits.

In juvenile specimens (microphotographed specimens GIT 698-29 and GIT 298-30) reticulate ornament can be seen on the ventral area of the valve. 


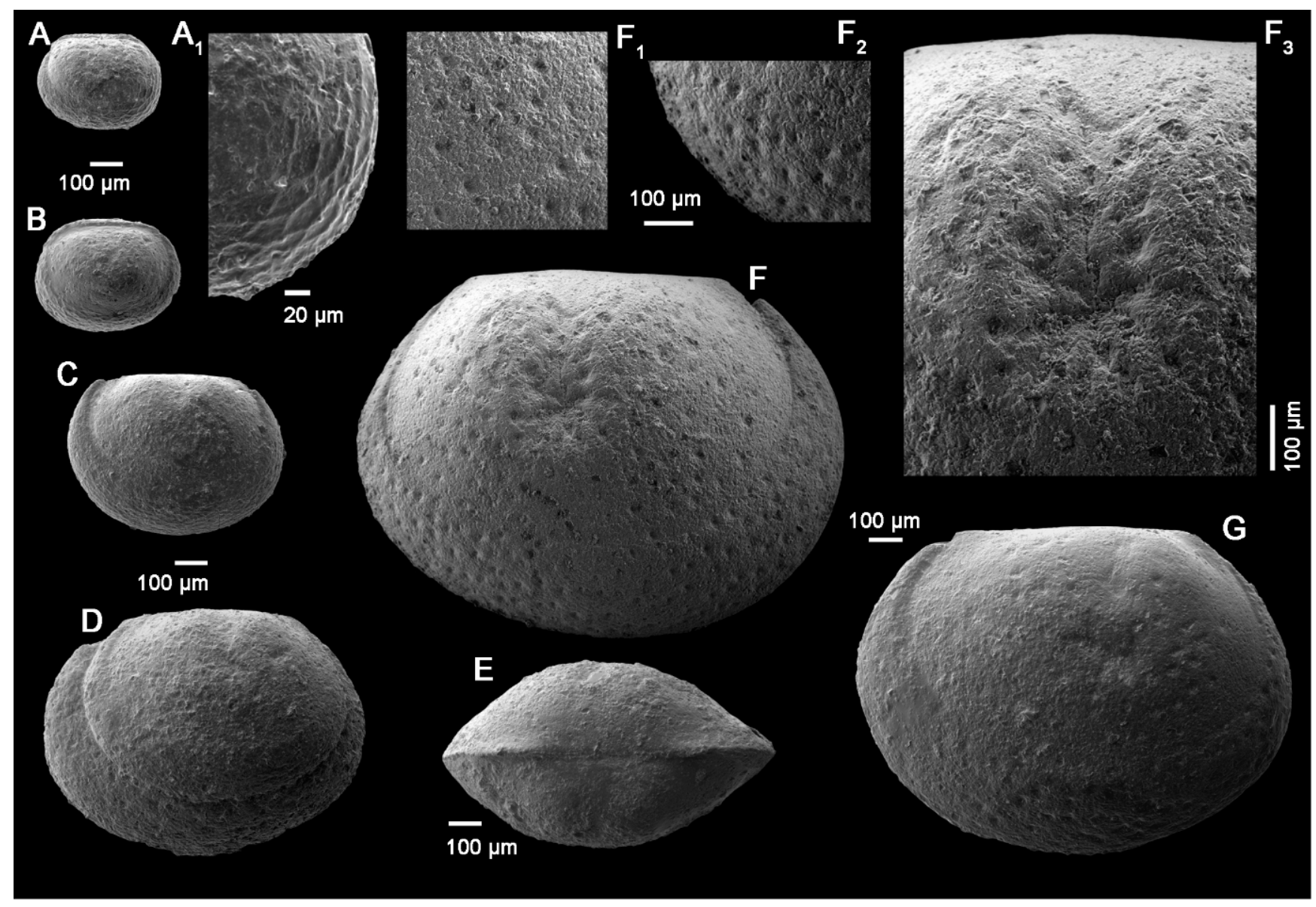

Fig. 3. Scanning electron photomicrographs of the new Eridostracan ostracod species Cryptophyllus pius sp. n., Upper Ordovician, collection number GIT-698, collected from Kętrzyn IG 1 drillcore, northeastern Poland

A - Cryptophyllus pius sp. n. (GIT 698-29), left valve of juvenile carapace; $\mathbf{A}_{1}-3.5 x$ magnification from photomicrograph A showing posteroto mid-ventral part of juvenile carapace with reticulation near its free margin; B - Cryptophyllus pius sp. n. (GIT 698-30), right valve of juvenile carapace; C - Cryptophyllus pius sp. n. (GIT 698-31), lateral view of right valve, older layers of carapace have disintegrated and left an imprint parallel to the free magin of the carapace to the youngest layer; D - Cryptophyllus pius sp. n. (GIT 698-32), lateral view of right valve; $\mathbf{E}-$ Cryptophyllus pius sp. n. (GIT 698-35), dorsal view of carapace; F - Cryptophyllus pius sp. n. (GIT 698-34), older layers of carapace have disintegrated and left an imprint parallel to the free magin of the carapace to the youngest layer, distinct pitting is visible on the valve including median sulcus area and around the star-shaped pit $S 2 ; F_{1}-1.5 x$ magnification of posteromedian area of specimen $F$, clear pitting and imprint of the disintegrated older layers can be seen; $F_{2}-1.5 x$ magnification of anteroventral area of specimen $F ; F_{3}-2 x$ magnification of the sulcal and star-shaped pit S2 area of the photomicrograph of specimen F; G - Cryptophyllus pius sp. n. (GIT 698-33), lateral view of right valve, older layers of carapace have disintegrated and left an imprint parallel to the free magin of the carapace to the youngest layer, on the anteromedian area of the valve a star-shaped pit can be seen

O c c u r r e n c e. - Hirnantian Stage of northeastern Poland, Kętrzyn IG 1 borehole.

L o c a lity. - Kętrzyn IG 1 borehole; depths 1551.2-1549.8 m; $1546.2 \mathrm{~m} ; 198$ specimens recorded.

\section{OSTRACOD DATA}

Altogether, 46 samples were taken from the Kętrzyn borehole. Ostracods were picked from 10 of them (Fig. 4). Eight ostracod samples come from the uppermost Ordovician Prabuty Formation and the remaining two from the Pasłęk Formation, dated as the lowermost Silurian (Modliński et al., 2002). A total of 619 ostracod specimens belonging to 35 species (including the new eridostracan species Cryptophyllus pius sp. n.) of 28 genera were identified. About half of them belong to the suborder Binodicopa, metacopes are also abundant $(22.8 \%$ of the whole number of specimens). Surprisingly, we found some eridostracans in our material. They are abundant $(22.4 \%$ of the whole number of specimens) and the dominant species in the Kętrzyn drillcore material is also the eridostracan species Cryptophyllus pius sp.n.

The ostracod material in the Baltic Palaeobasin comprises three successive assemblages which are described here along a deepening facies belt.

\section{THE PRE-HIRNANTIAN ASSEMBLAGES}

The Late Ordovician ostracod fauna in Baltoscandia is of high diversity and dominated by metacopes. The dominance of metacopes is more evident in the sections of the Estonian Shelf (Figs. 5 and 6). For example, in the northern and western Estonian cores (Moe, Orjaku, Virtsu cores), the most abundant species are Medianella blidenensis (Gailīte), Steusloffina cuneata (Steusloff), Rectella nais Neckaja and Olbianella fabacea (Pranskevičius) (Meidla, 1996b). The species are present in all 

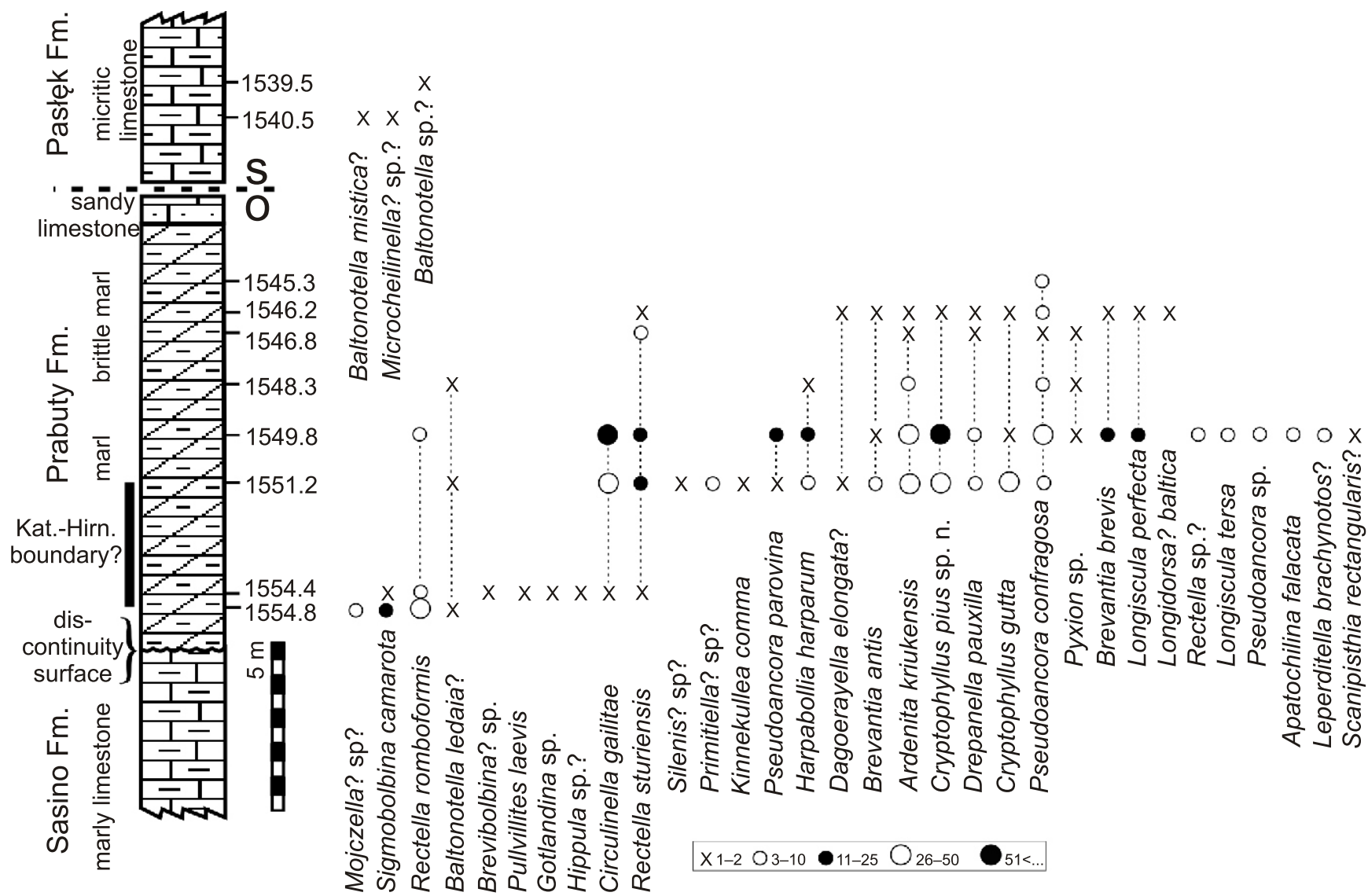

Fig. 4. Distribution chart of the ostracods collected from the uppermost Ordovician and lowermost Silurian strata of Kętrzyn IG 1 drillcore

three cores and comprise the most abundant species in the recorded assemblages. The pre-Hirnantian ostracod association described in the Råssnäsudden section in Östergötland, Sweden, contains about $50 \%$ of metacopes, but the composition of the assemblage is different. The most abundant species in this section are Daleiella rotundata and Rectella romboformis, and the assemblage has common features with the association from the topmost Ordovician strata in the Pärnu core (Meidla, 1996b: 188, Fig. 40, 241-247 m). Other species belong mostly to palaeocopes and binodicopes (Truuver et al., 2012) and the same species are widespread and common in the pre-Hirnantian of Estonia (Meidla, 1996b), Latvia (Gailite in Ulst et al., 1982) and Lithuania (Sidaravičiene, 1992, 1996). The genera Medianella, Steusloffina and Rectella are common in northwestern Estonia and range also into the reef limestones of the Ärina Formation (Porkuni Stage). Meidla (1996b) distinguished the Steusloffina cuneata-Olbianella fabacea association in the limestones of the Moe and Adila formations (uppermost Katian).

Southwards, i.e. along the deepening facies profile, the dominance of metacopes becomes less evident, but the most abundant species are still mostly metacopes - Pullvillites laevis Abushik et Sarv, Longiscula perfecta Meidla and Medianella blidenensis. Most of the ostracod genera still belong to the suborder Palaeocopa, but this material is much less numerous compared to the metacope species (Meidla, 1996a, b).

The most abundant long-ranging species in eastern Latvia seem to be Steusloffina cuneata, Tetradella litwiensis Neckaja and Leperditella brachynotos (Schmidt). In the deeper shelf setting, in western Latvia, Medianella blidenensis, Piretella acmacea Öpik, Sigmobolbina camarota Jaanusson and
Pseudoancora parovina (Sidaravičiene, 1975) are the most abundant and widespread species (Ulst et al., 1982). Steusloffina cuneata is common also in Lithuania (Sidaravičiene, 1996: 41), but abundance of palaeocopes is higher, and leiocopes (e.g., Baltonotella mistica, B. ledaia and $B$. limbata) are also abundant, especially in the pre-Hirnantian (Sidaravičiene, 1992).

The Katian ostracod assemblage in northeastern Poland (Sztejn, 1985) is dominated by palaeocopes (56\% of the species) and binodicopes (32\%), but new data from the Kętrzyn IG 1 borehole suggest that metacopes may be underrepresented in the published collections. The species composition of palaeocopes and binodicopes is still similar to the ostracod associations in the pre-Hirnantian of other parts of Baltoscandia. Steusloffina cuneata is still recorded in some sections of northeastern Poland.

\section{THE HIRNANTIAN ASSEMBLAGES}

In the Kętrzyn IG 1 borehole, the binodicope taxa constitute about a half of the total number of the Hirnantian ostracod taxa. This feature is common with the Harpabollia harparum association where the proportion of binodicopes increases markedly, compared to the older assemblages. The $H$. harparum association is interpreted as an immigrating cool-water assemblage (Meidla, 1996b, 2007). This association is considered to be indicative of the Hirnantian in the Baltoscandian area or even wider geographical area (see Schallreuter, 1990). In the Baltoscandian area it is confined to the areas of the Scandinavian Basin (corresponding to the Central Baltoscandian 
Central Baltoscandian Basin Livonian Tongue $\quad$ North Estonian Basin/Lithuanian Basin

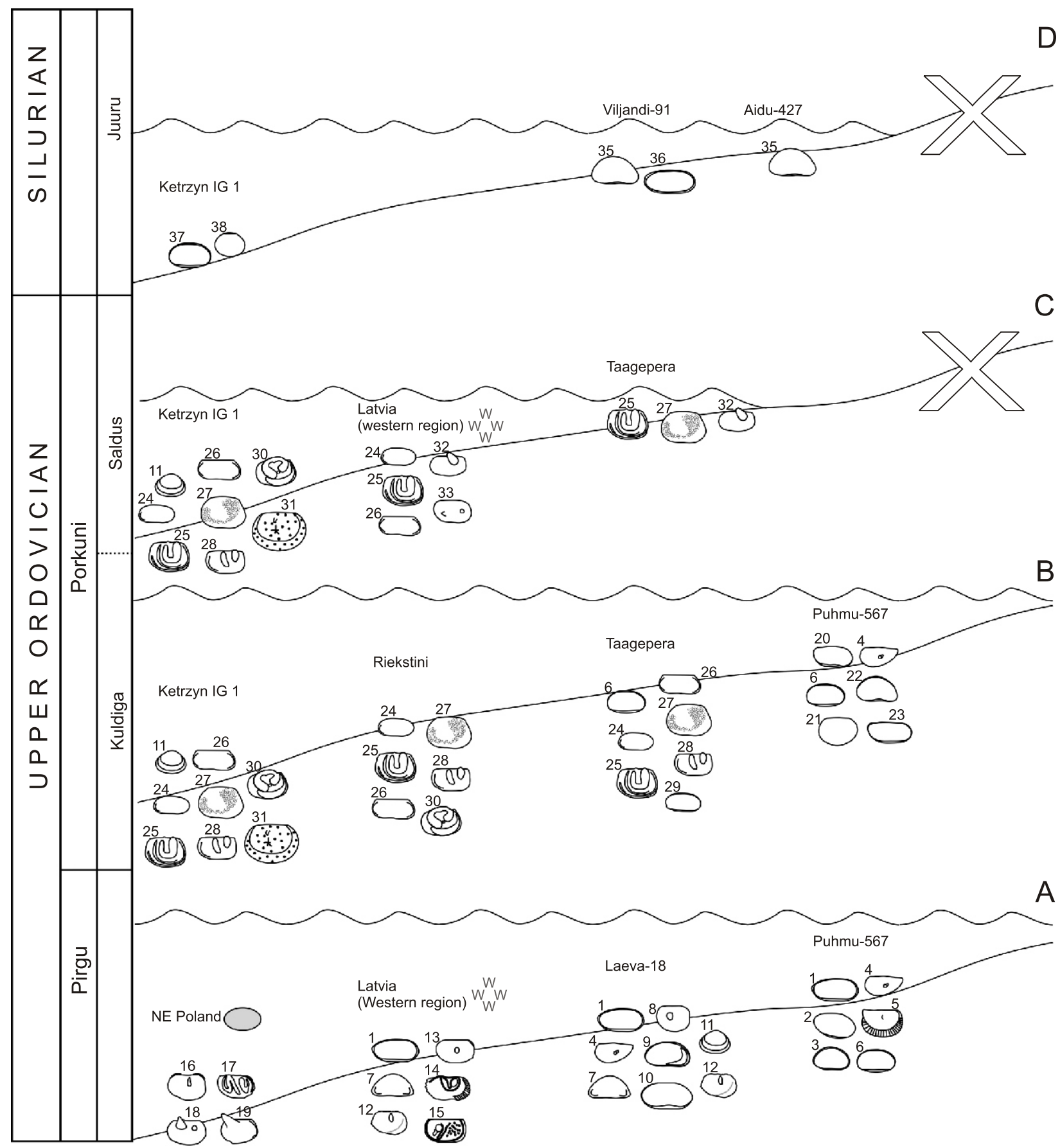

Fig. 5. Development of ostracod associations on the Baltic shelf during the end-Ordovician and lowermost Silurian climatic events (uppermost Katian-lower half of Rhuddanian)

The most common and abundant ostracod species of each location discussed in the article are brought out to show the diversity of ostracod population in the Baltic Palaeobasin during the Upper Ordovician, gradual decline of their diversity throughout the Hirnantian crisis, and the strong faunal change at the beginning of the glaciation. The locations along the shelf model shows the transition of facies from the northern Estonian inner ramp south-westwards to the deeper water areas of northern and northeastern Poland, forming a facies profile along the shelf of the Baltic Palaeobasin (meant here not as a straight line but as a wider continuum of different facies). The Pirgu, Porkuni and Juuru are regional stage names and correspond to the international stages of Katian, Hirnantian and Rhuddanian (respectively). The models of palaeobasin next to the time scale reflect the following periods of time: model A - pre-Hirnantian, models B, C - Hirnantian glacial period, model D - post-glacial period. Locations of the drillcores are marked in Figure 1. Each ostracod species is marked with a number; 1 Medianella blidenensis, 2 - M. intecta, 3 - Olbianella fabacea, 4 - Steusloffina cuneata, 5 - Platybolbina orbiculata, 6 - Microcheilinella lubrica, 7 - Pullvillites laevis, 8 - Gryphiswaldensia plavinensis, 9 - Rectella explanata, 10 - R. romboformis, 11 - Cryptophyllus gutta, 12 Uhakiella curta, 13 - Tvaerenella expedita, 14 - Piretella acmaea, 15 - Sigmobolbina camarota, 16 - U. jonesii, 17 - Tetradella egorowi, 18 Pseudulrichia disputabile, 19 - Ps. tubulata, 20 - M. aequa, 21 - Leperditella brachynotos, 22 - Bairdiocypris indeterminatus, 23 - M. longa, 24 - Rectella sturiensis, 25 - Harpabollia harparum, 26 - Pseudoancora confragosa, 27 - Circulinella gailitae, 28 - Drepanella? pauxilla, 29 - R. composita, 30 - Ardenita kriukensis, 31 - Cryptophyllus pius sp.n., 32 - Aechmina groenwalli, 33 - Spinopleura porkuniensis, 34 Longiscula cf. smithii, 35 - L. cf. smithii, 36 - Microcheilinella rozhdestvenskaja, 37 - Microcheilinella sp., 38 - Baltonotella mistica 
N Estonia, Ärina Fm.

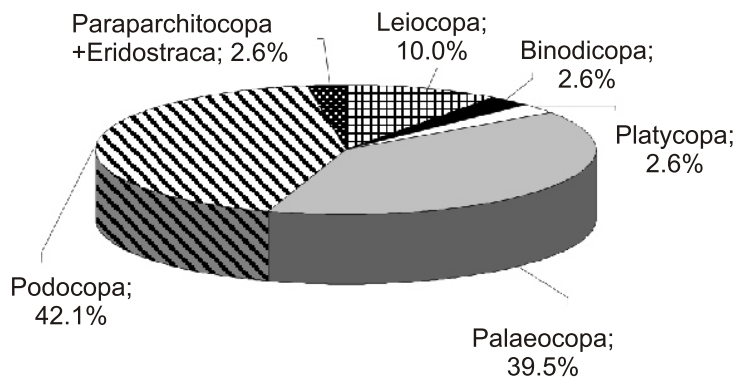

S Estonia and W Latvia, Kuldiga Fm.

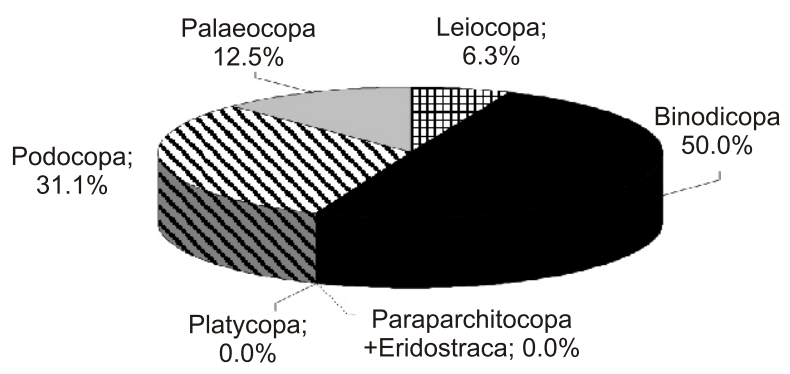

NE Poland, Prabuty Fm.

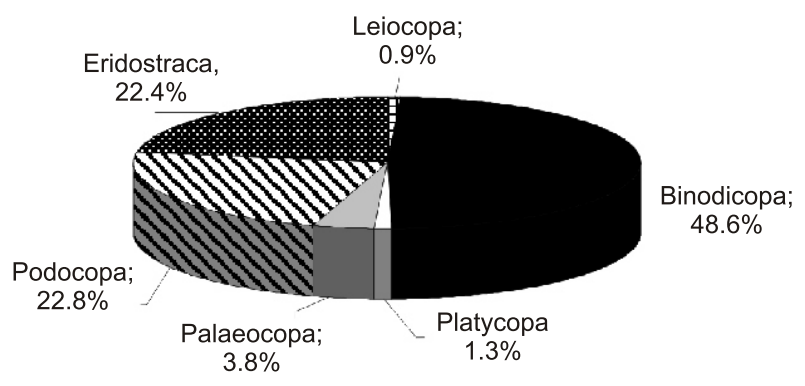

Fig. 6. Generic structure of the uppermost Ordovician ostracod associations in Baltoscandia (after Meidla, 1996a: fig. 1)

Confacies Belt of Jaanusson (1976) being recorded in Sweden (Troedsson, 1918; Bergström and Bergström, 1996; Meidla, 2007), Latvia (Gailīte, 1970; Meidla in Brenchley et al., 2003; Meidla et al., 2011), Estonia (Meidla, 1996a, b), Poland (Sztejn, 1985), Lithuania (Sidaravičiene, 1992) and Estonia (Meidla, 1996b, 2007; Meidla in Brenchley et al., 2003). Specimens of species Harpabollia harparum (Troedsson), Aechmina groenwalli (Troedsson), Rectella sturiensis Gailite and Circulinella gailitae Meidla form the vast majority of the Borenshult collection (Meidla, 2007).

$H$. harparum, C. gailitae and $R$. sturiensis are represented also in the Hirnantian of Kętrzyn (Fig. 7) whilst $A$. groenwalli is missing. The most abundant genus in the Prabuty Formation at Kętrzyn is Cryptophyllus, which is represented by 139 specimens. About $1 / 4$ of them belong to $C$. gutta Schallreuter. The majority of the specimens of this genus belong to a new species
Cryptophyllus pius sp. n. (Fig. 8). Other abundant species in the Hirnantian part of the Kętrzyn IG 1 borehole are Pseudoancora confragosa, $P$. parovina and Ardenita kriukensis Sidaravičiene. $P$. confragosa is also known from South Estonia, Latvia and Lithuania whilst Ardenita kriukensis has formerly been described in Lithuania, Latvia (Brenchley et al., 2003) and in the Borenshult locality (Meidla, 2007). Other common ostracod species in the collections from Poland and Lithuania, Harpabollia harparum (Troedsson) and Drepanella pauxilla Gailite, are typical members of the Harpabollia harparum association. In Latvia and Estonia, the aforementioned species co-occur with Rectella romboformis Neckaja, $R$. sturiensis Gailīte and Scanipisthia rectangularis (Troedsson) (Gailīte, 1970, Gailite in Ulst et al., 1982; Meidla, 1996b; Meidla in Brenchley et al., 2003; Meidla et al., 2011). In Estonia, the Harpabollia harparum association is confined to the southernmost areas (Taagepera, Abja, Otepää, Ruhnu cores).

A unique feature of the ostracod material from Kętrzyn is the relatively high number of species previously documented only from the pre-Hirnantian strata. The occurrence of Cryptophyllus gutta, Baltonotella ledaia, B. limbata, Pullvillites laevis, Leperditella brachynotos and Sigmobolbina camarota together with members of the Harpabollia harparum association has not been documented so far.

\section{THE POST-GLACIATION FAUNA}

The post-Hirnantian fauna in the Kętrzyn section is poor. The disappearance of binodicope-rich assemblages must be considered, as only a few specimens of Baltonotella sp. indet. were collected. This change, however, is consistent with many other sections. The basal part of the strata earlier attributed to the Silurian is barren or contains an impoverished ostracod assemblage with the species composition conspicuously different from that of the underlying stratigraphical level (e.g., Neckaja, 1966; Pranskevičius, 1975). None of the recorded species range from the uppermost Ordovician to the Silurian with certainty in the Eastern Baltic region. The Silurian record of Medianella aequa and Microcheilinella lubrica (Pranskevičius, 1972) could not be proved as the collection seems to be lost (observations by T. Meidla in 2011).

The new ostracod associations above the strata with the Medianella aequa and Harpabollia harparum associations is of low diversity. The prevailing species are metacopes Longiscula smithii and Microcheilinella rozhdestvenskaja (Meidla, 1996b). Metacopes are dominant also in Latvia and Lithuania, although the species spectrum is different, comprising e.g., Longiscula elongata, Microcheilinella angulosa, M. composita, Rishona peculiaris, but also some species present in Upper Ordovician strata as well e.g., Bairdiocypris indeterminatus and Pullvillites laevis (Pranskevičius, 1975).

The post-Hirnantian ostracod assemblage described at Råssnäsudden is somewhat different from the rest of the Baltoscandian ostracod assemblages, but the strata overlying the pre-Hirnantian (dated by Truuver et al., 2012) are likely equivalent to the middle Llandovery. A substantial gap in the section likely corresponds to the Hirnantian and some post-Hirnantian. Two species, Microcheilinella rozhdestvenskaja Neckaja and Gotlandina erratica Schallreuter seem to range from the pre-Hirnantian to the post-Hirnantian. The ostracod assemblage in the Motala Formation is rather diverse. It contains predominantly metacopes, including the most abundant species of Longiscula smithii, Microcheilinella mobile Gailīte and M. globulosa Pranskevičius (Truuver et al., 2012). 


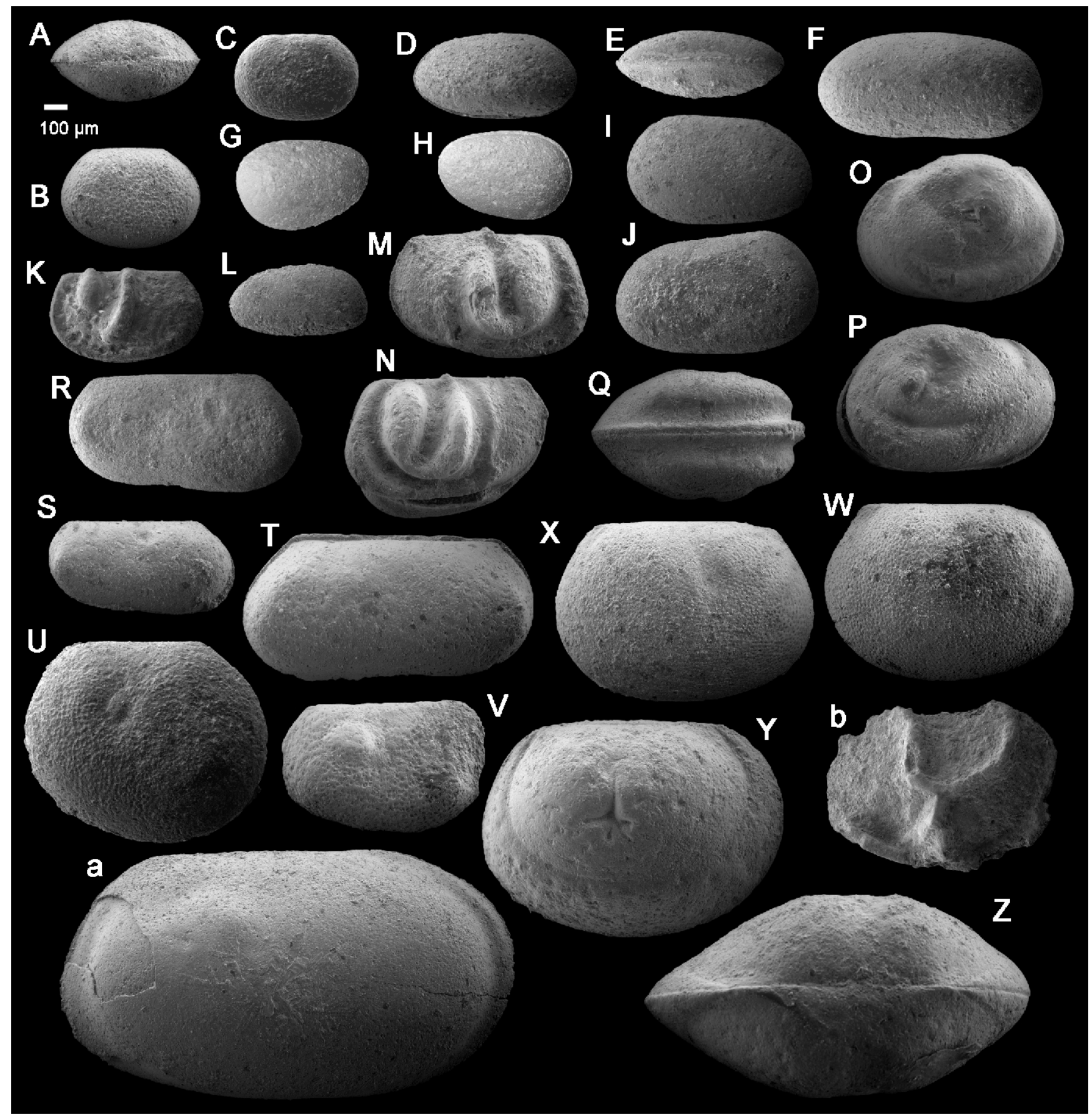

Fig. 7. Scanning electron photomicrographs of ostracods from the Kętrzyn IG 1 borehole, Upper Ordovician, collection number GIT-698, northeastern Poland

A-C Circulinella gailitae Meidla, 1996: A - dorsal view of carapace (GIT 698-1), B - lateral view of right valve (GIT 698-2), C - lateral view of left valve (GIT 698-3); D-F Rectella romboformis Neckaja, 1966: D - lateral view of right valve (GIT 698-5), E - ventral view of carapace (GIT 698-6), F - lateral view of right valve (GIT 698-7); G, H - Primitiella? sp.: G - lateral view of right valve (GIT 698-13), H - lateral view of left valve (GIT 698-12); I, J - Brevantia brevis Meidla, 1996: I - lateral view of right valve (GIT-698-17), J - lateral view of left valve (GIT 698-18); K - Drepanella pauxilla Gailīte, 1970, lateral view of left valve (GIT 698-11); L - Rectella cf. sturiensis Gailīte, 1975, lateral view of right valve (GIT 698-4); M, N - Harpabollia harparum (Troedsson, 1918): M - lateral view of right valve (GIT 698-14), N - lateral view of left valve (GIT 698-15); O-Q - Ardenita kriukensis Sidaraviciene, 1982: O - lateral view of right valve (GIT 698-20), P - lateral view of left valve (GIT 698-19), Q - ventral view of carapace (GIT 698-21), R - Pseudoancora parovina (Sidaravičiene, 1975). Lateral view of right valve (GIT 698-9); S, T - Pseudoancora confragosa: S - lateral view of right valve (GIT 698-8), T - lateral view of left valve (GIT 698-10); U - Circulina nuda Neckaja, 1966, lateral view of left valve (GIT 698-22); V - Brevibolbina? sp. (GIT 698-16); W-Z - Cryptophyllus pius sp. n.: W - lateral view of right valve (GIT 698-25), X - lateral view of right valve (GIT 698-24), Y - lateral view of incomplete left valve - older layers have disintegrated and only the youngest layer has been preserved (GIT 698-23), Z - dorsal view of incomplete carapace - older layers have disintegrated and only the youngest layer has been preserved (GIT 698-26); a - Tvaerenella? sp. lateral view of left valve (GIT 698-27); b Mojczella? sp. lateral view (GIT 698-28); all photomicrographed specimens are to the same scale 

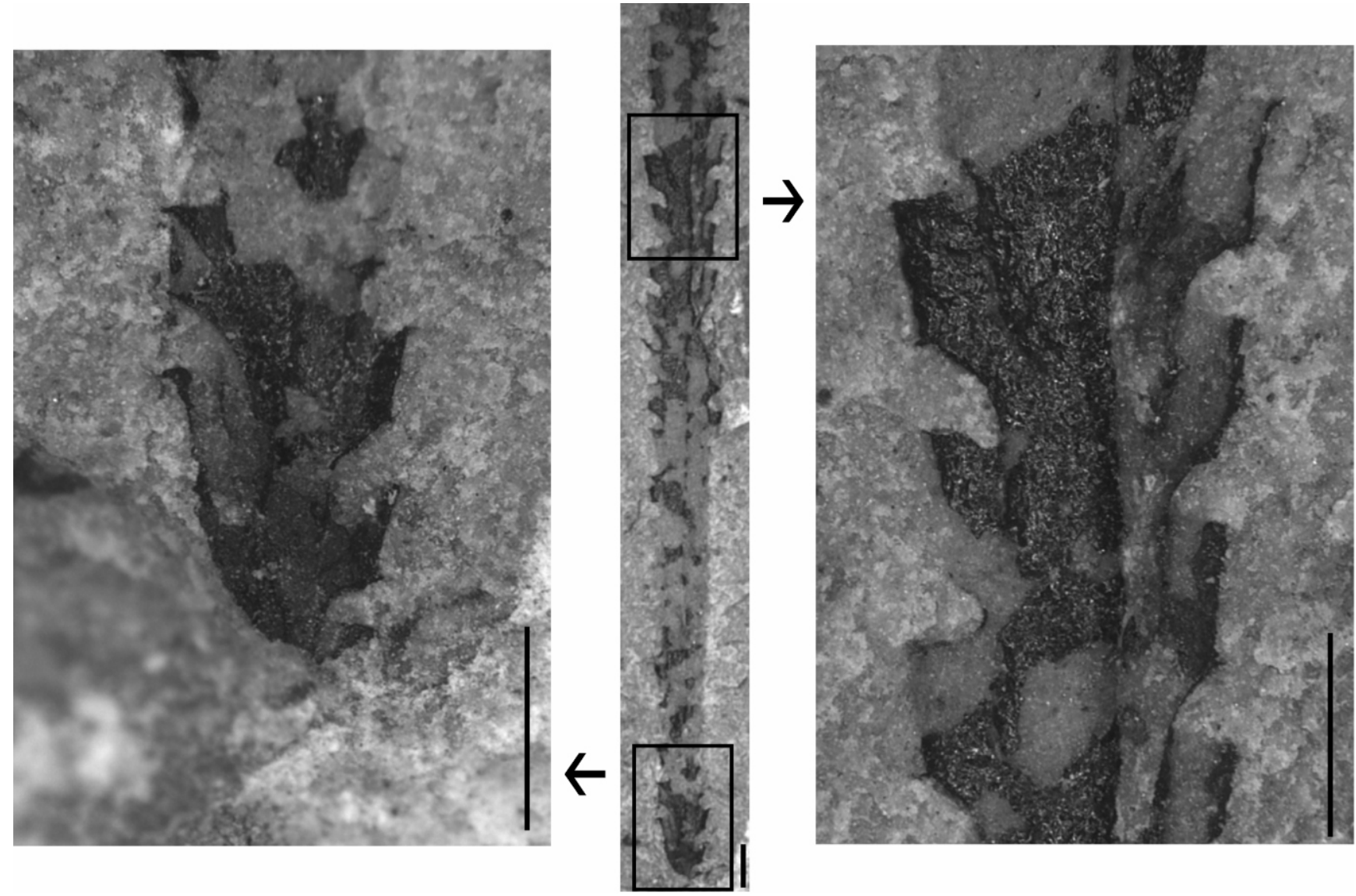

Fig. 8. A probable Normalograptus persculptus found with the $H$. harparum fauna of the Borenshult location

Black bar in every picture is $1 \mathrm{~mm}$

The new faunal assemblages above the strata with the Medianella aequa and Harpabollia harparum were formerly attributed to the Silurian.

\section{DISCUSSION}

The end-Ordovician ostracod fauna in Poland is well-known. Earlier papers deal with Ordovician ostracods in northeastern Poland (Sztejn, 1985) and the Podlasie Depression and Lublin region (eastern Poland; Sztejn, 1989). Nevertheless, the latest Ordovician ostracod assemblages are rather poor, compared to the 35 ostracod species collected from Hirnantian strata of the Kętrzyn borehole.

Despite relatively scarce data, the latest Ordovician assemblages in the study areas reveal considerable differences. The ostracod assemblage in northeastern Poland (Sztejn, 1985) contains typical representatives of the Harpabollia harparum association: Harpabollia harparum, Aechmina groenwalli, Drepanella pauxilla (Klimphores pauxilla in Sztejn, 1985) and Scanipisthia rectangularis. The latest Ordovician ostracod fauna in eastern Poland seems to be scarce overall, however, the few documented taxa are common in the Ärina Formation of North Estonia. These two areas are assigned to different biogeographic regions by Meidla et al. (2013). Eastern Poland shows a close biogeographic affinity to North Estonia whilst northeastern Poland is closely related to West Latvia and West Lithuania, the distribution area of the Harbabollia harparum association (Meidla et al., 2013: 350, fig. 21.7). This confirms that the general facies pattern in northeastern Poland resembles that in Estonia, with onshore assemblages in eastern Poland (as an extension of the Lithuanian Basin) and deeper water (distal ramp) assemblages more west and northwest of the previous area (southern extension of the Scandinavian Basin; see also Fig. 1).

A unique feature of the Kętrzyn ostracod association is the relatively diverse ostracod assemblage. In addition to the typical elements of the $H$. harparum association $(H$. harparum, Pseudoancora confragosa, Ardenita kriukensis) it also contains some metacopes (Dagoerayella elongata, Brevantia brevis, Pullvillites laevis) and eridostracans (Cryptophyllus gutta) that were previously not recorded together with the Harpabollia harparum association. Some genera in these subfamilies are diverse and abundant in South Estonian (e.g., in Taagepera core section), and Latvian (Ulst et al., 1982) pre-Hirnantian successions, but sparse or absent in the Hirnantian Stage of these areas. This kind of species composition, where pre-Hirnantian species co-exist with taxa specific to the Hirnantian Stage, is up to now unknown from any other part of the Baltoscandian region.

The Prabuty Formation was attributed to the Pirgu and Porkuni stages in most previous papers (e.g., Bednarczyk et al., 1996; Modliński and Szymański, 1997; Modliński and Podhalańska, 2010). This assignment gains further support from the ostracod evidence. The ostracod assemblage in the lowermost sample $(1554.8 \mathrm{~m})$ is characterized by a lack of elements of the $H$. harparum association. Some $40 \mathrm{~cm}$ above, the appearance of Circulinella gailitae is recorded, whilst three 
metres higher (1551.2 $\mathrm{m}$ ) the assemblage composition shows a strong affinity to the $H$. harparum association together with Eostropheodonta hirnantensis (M'Coy) (Rubel in Modliński et al., 2002). It suggests that the base of the Hirnantian Stage in the Kętrzyn IG 1 borehole could be drawn in the interval of 1551.2-1554.8 m, higher than suggested by Modliński et al. (2002). The stable isotopic evidence from this section is not available and the chitinozoan (Modliński et al., 2002) evidence is insufficient for distinguishing the Pirgu and Porkuni stages in this section. The interval 1544.5-1558.6 m contains only a few long-ranging chitinozoans or barren samples (Modliński et al., 2002).

The assemblage in the middle Prabuty Formation of the Kętrzyn IG 1 borehole is dominated by Cryptophyllus pius sp. $\mathrm{n}$. This type of assemblage, where the dominant species is an eridostracan, is unknown in other locations of the $H$. harparum association (Fig. 6). The assemblage has a clearly transitional character between the Medianella aequa and $H$. harparum assemblages. We may assume that the transitional assemblage was very likely characteristic of the transition zone (Central Estonia, eastern Latvia) where the preserved strata of this age are nearly barren because of very shallow-water origin (oolitic limestones) or as a consequence of later dolomitization. The strata in the transitional area have also been subjected to erosion (note the lack of strata in an extensive belt in Central Estonia in Hints and Männik, 2014: 169, fig. 3).

The recovery of fauna in Kętrzyn is very poor, even if compared with impoverished faunas in the overlying strata in South Estonia and Latvia. The overall picture still fits the "model" drawn by Meidla et al. (2011) where the $H$. harparum association is replaced by an impoverished assemblage of "Silurian" taxa (Longiscula smithii, Microcheilinella mobile). The appearance of aforementioned taxa usually marks a complete turnover, with no (or very few) species ranging from the $H$. harparum-type assemblage into the overlying strata. An exception here seems to be the Råssnäsudden section in Östergötland (Sweden; Truuver et al., 2012) in spite of the fact that the succession of the Ordovician-Silurian boundary interval seems to be incomplete, with the Hirnantian and lowermost Silurian missing (Bergström and Bergström, 1996; Truuver et al., 2012).

In the South-Estonian Taagepera drillcore (Meidla, 1996b; Brenchley et al., 2003) the uppermost part of the Ordovician is represented by the Kuldiga and Saldus formations. The ostracod assemblage in the Kuldiga Formation is more diverse than in the overlying Saldus Fm. and it can be divided to two parts based on ostracod species distribution: the assemblage in its lower part is dominated by the species Microcheilinella lubrica, Rectella composita and $R$. romboformis. In the middle-upper parts of the formation the role of metacopes decreases considerably, which are replaced by Harpabollia harparum, Pseudoancora confragosa and Circulinella gailitae (Meidla, 1996b; Meidla et al., 2011). This could be interpreted as a kind of transitional assemblage, although most of the metacopes are represented by long-ranging taxa. This kind of differentiation does not appear in the Kętrzyn collection.

The Latvian and Lithuanian Hirnantian ostracod associations (Ulst et al., 1982; Sidaravičiene, 1992, respectively) also display a remarkable overlap of the species.

Sztejn (1985) emphasizes the relationships between the ostracod distribution and sedimentary environments in the Baltoscandian Palaeobasin. In the shallow shelf setting characterized by marls and marly limestones the ostracods are abundant and diverse. In a deeper-water distal ramp setting, where claystones begin to dominate, a decline of ostracod abundance until their total disappearance is observed. Diversity differences between the Hirnantian ostracod assemblages are discussed also by Meidla (1996a). The transitional ostracod assemblage in the Kętrzyn borehole, with its specific composition was likely established due to the end-Ordovician glaciation and overturn of the former habitats. The Kętrzyn area in the offshore zone could have acted as a refuge for some time, at the beginning of the glaciation, where the conditions were tolerable for some eurytopic long-ranging Ordovician ostracod species, at least for a short time.

Dating of the $H$. harparum association in terms of graptolite zonation requires further study. In the former generalizations (e.g., Brenchley et al., 2003) the strata containing this association were divided between the Normalograptus extraordinarius and $N$. persculptus biozones. In more recent papers (e.g., Meidla et al., 2011; Ainsaar et al., 2015) the fact that the glaciation was mostly restricted to the Normalograptus extraordinarius Biozone is taken into account. The upper Hirnantian N. persculptus Biozone is thought to correspond to a gap, at least in Central Estonia. Nevertheless, the co-occurrence of the species of the $H$. harparum association and $N$. persculptus has been recorded in the Borenshult locality, where the ostracods and the graptolite specimen occur on the same rock slab (Meidla, 2007; Bergström et al., 2011). Although the identification of the graptolite specimen $\mathrm{Cn} 67772$ in the collections of the Naturhistoriska Riksmuseet (see Fig. 8) has been questioned (see Bergström et al., 2012 for the discussion), it is not excluded that the $H$. harparum association may partly be of early Late Hirnantian age.

The new faunal assemblages above the strata with the Medianella aequa and Harpabollia harparum associations was formerly (Gailīte, 1968; Meidla, 1996b; Sarv and Meidla, 1997) attributed to the Silurian. In the light of recent studies (Meidla et al., 2011, 2014; Ainsaar et al., 2015), the new emerging assemblage should be dated as the latest Hirnantian-Silurian. The appearance level of the so-called Silurian ostracod fauna in the Jurmala core section is clearly related to the decreasing values of $\delta^{13} \mathrm{C}$ of the isotopic curves of the Hirnantian excursion and should therefore be considered as late Hirnantian. Recent evidence has shifted the lower boundary of the Silurian System upwards in some other regions too (e.g., North America Bergström et al., 2012; subpolar Urals - Beznosova et al., 2011), and this boundary should likely be reconsidered also in the Baltoscandian Palaeobasin (Ainsaar et al., 2015).

\section{CONCLUSIONS}

Though the Polish end-Ordovician ostracods are well-known, the material from the Kętrzyn IG 1 borehole shows much higher diversity than documented in former studies. The ostracod assemblage in northeastern Poland (Sztejn, 1985) contains typical representatives of the Harpabollia harparum association: Harpabollia harparum, Aechmina groenwalli, Drepanella pauxilla (Klimphores pauxilla in Sztejn, 1985) and Scanipisthia rectangularis.

The scarce latest Ordovician ostracod fauna in eastern Poland (Sztejn, 1989) differs from the Harpabollia harparum association. It shows some affinity with the Ärina Formation of North Estonia, assigned to the same biogeographic region (Meidla et al., 2013). This suggests that the general facies pattern in northeastern Poland resembles that in Estonia, with onshore assemblages in eastern Poland and distal ramp assemblages more west and north-west of the previous area.

The ostracod evidence from the present study confirms the previous assignments of the Prabuty Formation to the Hirnantian Stage, and places the Katian-Hirnantian boundary 
in the Kętrzyn IG 1 borehole to the interval of 1551.2-1554.8 m. This confirms the Pirgu-Porkuni age of the Prabuty Formation together with Eostropheodonta hirnantensis (M`Coy) (Rubel in Modliński et al., 2002). This interpretation does not contradict the brachiopod evidence from the Prabuty Formation.

The Early-Middle Hirnantian ostracod assemblage is characterized by less apparent dominance of binodicopes and can be interpreted as a transitional faunal assemblage that was not previously discovered (or is not preserved) in other parts of the Baltoscandian Palaeobasin.

Sztejn (1989) pointed out a clear interconnection between ostracod associations and the sedimentary environment in the Baltic Palaeobasin. The Hirnantian assemblage at Kętrzyn probably acted as a kind of refuge to more resilient pre-Hirnantian ostracod species at the beginning of glaciation, being established due to the end-Ordovician glaciation and overturn of the former habitats.

Although dating of the $H$. harparum association in terms of graptolite zonation requires further study it is evident that the appearance of the assemblage co-occurs with the onset of the stable carbon isotopic excursion (Ainsaar et al., 2010) that is correlated to the appearance level of Normalograptus extraordinarius. Still, the likely coexistence of species of the $H$. harparum association and Normalograptus persculptus has been recorded in the Borenshult locality, where the indicative ostracods and the zonal graptolite occur on the same rock slab (Meidla, 2007; Bergström et al., 2011), suggesting that the H. harparum association may partly be of early Late Hirnantian age.

The latest studies demonstrate that the so-called "Silurian recovery fauna" should be dated as the latest Hirnantian-Silurian to shift the Ordovician-Silurian System boundary upwards in several regions (Ainsaar et al., 2015 and references therein). Our study of the ostracods suggests that shifting that boundary should be considered as well in the Baltoscandian Palaeobasin, and this may also apply to sections in northwestern Poland.

Acknowledgements. We would like to thank J. Nõlvak (Tallinn University of Technology, Estonia) for collecting and providing us with the ostracod material from the Kętrzyn IG 1 borehole, and O. Tinn and L. Ainsaar (University of Tartu, Estonia) for all of their useful comments and support during writing this paper. We are also greatly indebted to the reviewers of this article, C. Dojen (Regional Museum of Carinthia, Austria) and M. Williams (University of Leicester, UK), for their very useful and thorough comments and corrections. This study was supported by the Estonian Science Foundation grant 8049 "Biotic recovery events in the Ordovician and Silurian" and the Estonian Research Agency IUT20-34 "The Phanerozoic journey of Baltica: sedimentary, geochemical, and biotic signature of changing environment - PaleoBaltica".

\section{REFERENCES}

Abushik, A., Sarv, L., 1983. Ostrakody molodovskogo gorizonta Podolii (in Russian). In: Paleontologiya drevnego paleozoya Pribaltiki i Podoli (ed. E. Klaamann): 101-134, Tallinn.

Ainsaar, L., Meidla, T., Martma, T., 2004. The middle Caradoc facies and faunal turnover in the late Ordovician Baltoscandian palaeobasin. Palaeogeography, Palaeoclimatology, Palaeoecology, 210: 119-133.

Ainsaar, L., Kaljo, D., Martma, T., Meidla, T., Männik, P., Nõlvak, J., Tinn, O., 2010. Middle and Upper Ordovician carbon isotope chemostratigraphy in Baltoscandia: a correlation standard and clues to environmental history. Palaeogeography, Palaeoclimatology, Palaeoecology, 249: 189-201.

Ainsaar, L., Truumees, J., Meidla, T., 2015. The position of the Ordovician-Silurian boundary in Estonia tested by high-resolution $\delta^{13} \mathrm{C}$ chemostratigraphic correlation. In: Chemostratigraphy. Concepts, Techniques and Applications (ed. Mu. Ramkumar): 395-412. Elsevier.

Bednarczyk, W., 1968. Ordovician of Kętrzyn region (NE Poland) (in Polish with English summary). Acta Geologica Polonica, 18: 707-749.

Bednarczyk, W., Hints, L., Podhalańska, T., 1996. Later Ashgillian (Hirnatian) in Poland. In: The Third Baltic Stratigraphical Conference, 14 (ed. T. Meidla). Tartu.

Bergström, S.M., Bergström, J., 1996. The Ordovician-Silurian boundary successions in Östergötland and Västergötland, S Sweden. GFF, 118: 25-42.

Bergström, S.M., Schmitz, B., Saltzman, M.R., Huff, W.D., 2010. The Upper Ordovician Guttenberg $\delta^{13} \mathrm{C}$ excursion (GICE) in North America and Baltoscandia: occurrence, chronostratigraphic significance, and paleoenvironmental relationships. GSA Special Papers, 466: 37-67.

Bergström, S.M., Calner, M., Lehnert, O., Noor, A., 2011. A new upper Middle Ordovician-Lower Silurian drillcore standard succession from Borenshult in Östergötland, southern Sweden, 1 Stratigraphical review with regional comparisons. GFF, 133 149-171.
Bergström, S.M., Lehnert, O., Calner, M., Joachimski, M.M., 2012. A new upper Middle Ordovician-Lower Silurian drillcore standard succession from Boresnhult in Östergötland, southern Sweden, 2. Significance of $\delta^{13} \mathrm{C}$ Chemostratigraphy. GFF, 134: 39-63.

Beznosova, T.M., Maidl, T.V., Männik, P., Martma, T, 2011. The Ordovician-Silurian boundary on the western slope of the Subpolar Urals. Stratigraphy and Geological Correlation, 19: 385-403.

Biernat, G., 1973. Ordovician inarticulate brachiopods from Poland and Estonia. Palaeontologica Polonica, 28: 1-120.

Brenchley, P.J., Carden, G.A., Hints, L., Kaljo, D., Marshall, J.D., Martma, T., Meidla, T., Nõlvak, J., 2003. High-resolution stable isotope stratigraphy of Upper Ordovician sequences: constraints on the timing of bioevents and environmental changes associated with mass extinction and glaciation. GSA Bulletin, 115: 89-104.

Gailīte, L. 1968. Paleontological characteristics of adjacent Ordovician and Silurian deposits in Latvia (in Russian with english summary). In: Stratigrafiya Nizhnego Paleozoya Pribaltiki i Korrelyatsiya s Drugimi Regionami (ed. A. Grigelis): 130-138.

Gailīte, L., 1970. Ostracods from the Kuldiga Member of the Upper Ordovician of Latvia (in Russian with English summary). In: Paleontologiya i stratigrafiya Pribaltiki i Belorussii (ed. A.A. Grigelis): 19-32. Mintis.

Górka, H. 1969. Ordovician Microorganisms of Poland. Palaeontologia Polonica, 22: 1-172.

Henningsmoen, G., 1954. Lower Ordovician ostracodes from the Oslo region, Norway. Norsk Geologisk Tidsskrift, 33: 41-66.

Hints, L., Männik, P., 2014. Stop A10: Porkuni quarry. 4th Annual Meeting of IGCP 591. The Early to Middle Paleozoic Revolution. Estonia, 10-19 June 2014: 167-172.

Hints, L., Meidla, T., Nõlvak, J., Sarv, L., 1989. Some specific features of the late Ordovician evolution in the Baltic Basin. Proceedings of the Academy of Sciences of the Estonian SSR, Geology, 38: 83-87. 
Jaanusson, V., 1976. Faunal dynamics in the Middle Ordovician (Viruan) of Balto-Scandia. In: The Ordovician System: Proceedings of a Palaeontological Association Symposium Birmingham, September 1974 (ed. M. G. Bassett): 301-326. Cardiff, University of Wales Press and the National Museum of Wales for the Palaeontological Association.

Jaworowski, K., 1999. The Lower Palaeozoic craton margin depositional sequences in North Poland: record of the Caledonian Stage tectonic events. In: EUG 10, Journal of Conference Abstracts, 4. Cambridge Publications, Strasbourg.

Jaworowski, K., 2002. Profil dolnego paleozoiku w północnej Polsce - zapis kaledońskiego stadium rozwoju basenu bałtyckiego (in Polish). Posiedzenia Naukowe Państwowego Instytutu Geologicznego, 58: 9-10.

Kaljo, D., Hints, L., Martma, T., Nõlvak, J., 2001. Carbon isotope stratigraphy in the latest Ordovician of Estonia. Chemical Geology, 175: 49-59.

Kay, M. G., 1940. Ordovician Mohawkian ostracoda: Lower Trenton Decorah fauna. Journal of Paleontology, 129: 234-269.

Mees, J., Boxshall, G.A., Costello, M.J. et al., 2015. World Register of Marine Species. Available from http://www.marinespecies.org at VLIZ. Accessed 2015-10-26

Meidla, T., 1996a. Latest Ordovician ostracods of Baltoscandia. In: WOGOGOB-94 Symposium. Working Group of Ordovician Geology of Baltoscandia, Bornholm-94. (ed. S. Stouge), Geological Survey of Denmark and Greenland, Report 98: 63-68.

Meidla, T., 1996b. Late Ordovician ostracodes of Estonia. Fossilia Baltica, 2: 1-222.

Meidla, T., 2007. Ostracods from the Upper Ordovician Borenshult fauna, Sweden. GFF, 129: 123-132.

Meidla, T., Ainsaar, L., Truuver, K., 2011. Ostracods in Baltoscandia through the Hirnantian crises. Cuadernos del Museo Geominero, 14: 353-357.

Meidla, T., Tinn, O., Salas, M.J,M., Willliams, M., Siveter, D., Vandenbroucke, T.R.A., Sabbe, K., 2013. Biogeographical patterns of Ordovician ostracods. Early Palaeozoic Biogeography and Palaeogeography, 38: 337-354.

Meidla, T., Ainsaar, L., Hints, O., 2014. The Ordovician System in Estonia. In: 4th Annual Meeting of IGCP 591, Estonia, 10-19 June 2014. Abstracts and Field Guide (eds. H. Bauert, O. Hints, T. Meidla and P. Männik): 116-122. University of Tartu, Tartu.

Modliński, Z., Podhalańska, T., 2010. Outline of the lithology and depositional features of the lower Paleozoic strata in the Polish part of the Baltic region. Geological Quarterly, 54 (2): 109-121.

Modliński, Z., Szymański, B., 1997. The Ordovician lithostratigraphy of the Peribaltic Depression (NE Poland). Geological Quarterly, 41 (3): 273-288.

Modliński, Z., Nõlvak, J., Szymański, B., 2002. Chitinozoan biozonation of the Ordovician succession in the borehole Kętrzyn IG 1 (NE Poland) (in Polish with English summary). Przegląd Geologiczny, 50: 1149-1158.

Modliński, Z., Nõlvak, J., Szymański, B., 2007. Stratigraphy of the Ordovician and Silurian boundary deposists in northeastern Poland and their correlation with the stratotype sections in Estonia (in Polish with English summary). Biuletyn Państwowego Instytutu Geologicznego, 427: 61-78.

Neckaja, A.I., 1966. Ostrakody Ordovika i Silura SSSR (semejstva Schmidtellidae, Rectellidae, Longisculidae i nekotorye novye drugih semejstv) (in Russian). Trudy vsesoyuzhnogo neftyanogo nauchno-issledovatel'skogo geologorazvedochnogo instituta, 251: 1-103.
Olempska, E., 2012. Morphology and affinities of Eridostracina: Palaeozoic ostracods with moult retention. Hydrobiologia, 688: 139-165.

Oraspõld, A., 1975. Litologicheskaya harakteristika pirguskogo gorizonta $\vee$ Juzhnoy Estonii (in Russian). Uchenye zapiski Tartuskogo gosudarstvennogo universiteta:14-32, Trudy po geologii VII.

Podhalańska, T., 1999. The Upper Ordovician and the Lower Silurian in the Peribaltic Depression; stratigraphy and development. Acta Universitatis Carolinae, Geologica, 43: 221-224.

Pranskevicius, A. 1972. Ostrakody Silura yuzhnoy Pribaltiki (in Russian). Transactions of the Lithuanian Scientific Research Geological Survey Institute, 15: 1-280. Vilnius, Mintis.

Pranckevičius, A., 1975. Silurian podocopida of South Baltic area (in Russian with English summary). In: Fauna i Stratigrafija Paleozoja i Mezozoja Pribaltiki i Belorussii (ed. A.A. Grigelis): 85-91. Geological Board attached to the council of minister on Lithuanian SSR, Mintis, Vilnius.

Sarv, L., Meidla, T., 1997. Ostracodes. In: Geology and mineral resources of Estonia (eds. A. Raukas and A. Teedumäe): 233-234. Tallinn, Estonian Academy of Sciences.

Schallreuter, R., 1968. Zur Taxonomie und Phylogenie der Eridostraca (Ostracoda). Palaeontologische Zeitschrift, 42: 105-119.

Schallreuter, R., 1990. Ordovician ostracods and sea urchins of Carnic Alps and their relations to Bohemia and Baltoscandia (in German with English summary). Neues Jahrbuch für Geologie und Paläontologie Monatshefte, 1990: 120-128.

Schallreuter, R., Hinz-Schallreuter, J.U.C., 2010. Sexual dimorphism and pore systems in Ordovician ostracods. Acta Palaeontologica Polonica, 55: 741-760.

Sidaravičiene, N., 1992. Ostrakody ordovika Litvy (in Russian). Vilnius.

Sidaravičiene, N. 1996. Lietuvos ordoviko ostrakodai, biostratigrafija (in Lithuanian). Geologjos institutas, Vilnius.

Sztejn, J. 1985. Ordovician ostracods in North-Eastern Poland (in Polish with English summary). Biuletyn Instytutu Geologicznego, 350: 53-89.

Sztejn, J., 1989. Micropalaeontological stratigraphy of Ordovician in the Lublin area and the western part of Podlasie region (in Polish with English summary). Biuletyn Państwowego Instytutu Geologicznego, 363: 69-95.

Stempień-Sałek, M., 2011. Palynomorph assemblages from the Upper Ordovician in northern and central Poland. Annales Societatis Geologorum Poloniae, 81: 21-61.

Teller, L., 1997. The subsurface Silurian in the East European Platform. Palaeontologica Polonica, 56: 7-21.

Troedsson, G.T., 1918. Om Skånes brachiopodskiffer (in Swedish). Lunds Universitets Årsskrift N.F. (2), 15: 1-110.

Truuver, K., Meidla, T., Ainsaar, L., Bergström, J., Tinn, O., 2012. Stratigraphy of the Ordovician-Silurian boundary interval in Östergötland, Sweden, based on ostracod distribution and stable carbon isotopic data. GFF, 134: 295-308.

Ulst, R.Zh., Gailīte, L.K., 1970. Border of the Ordovician and Silurian of Latvia and the litho-stratigraphical subdivision of the boundary deposits. In: Palaeontology and Stratigraphy of the Baltic and the Byelorussia (ed. A.A. Grigelis): 283-295. Publishing house Mintis, Vilnius.

Ulst, R.Zh., Gailīte, L.K., Yakovleva, V.I., 1982. Ordovik Latvii (in Russian). Riga, Zinatne. 